\title{
International communication of Indonesia-China in the frame of yospan dance diplomacy
}

\author{
Dani Fadillaha, ,,* Wajiran ${ }^{\mathrm{a}, 2}$, Uspal Jandevi ${ }^{\mathrm{b}, 3}$ \\ a Universitas Ahamd Dahlan, Jl. Kapas No.9, Semaki, Kec. Umbulharjo, Kota Yogyakarta, Daerah Istimewa Yogyakarta 55166, Indonesia \\ ${ }^{\mathrm{b}}$ Nanjing Normal University, 122 Ninghai Rd, Gulou, Nanjing, Jiangsu, China \\ ${ }^{1}$ dani.fadillah@comm.uad.ac.id*; wajiran@enlitera.uad.ac.id; ${ }^{3} 30185309 @$ stu.njnu.edu.cn \\ * corresponding author
}

ARTICLE INFO

Article history

Received 2021-04-06

Revised 2021-06-01

Accepted 2021-06-17

Keywords

International Communication

Diplomacy

Culture

Yospan Dance

Indonesia-China

\section{ABSTRACT}

Diplomacy and communication between countries have real implications for intercultural encounters, and this position must be seen as an event that is not value-free. Indonesian people residing in China, primarily students, have informal tasks with a national mission, which plays an essential role in cultural communication and cultural diplomacy. They are Indonesian students who have artistic abilities, and every year they always put on performances, one of which is dance performances. This study describes how a traditional dance from Papua, Yospan, can be used as diplomacy between Indonesia and China. This research was conducted using a qualitative approach; each data obtained will be analyzed using international communication theory and soft diplomacy. This study found that traditional dances and literature in cultural missions are one of the tools of cultural diplomacy that can be used to change the stereotypes and prejudices of foreigners about Indonesia. The conclusion in this study shows that traditional culture is a powerful way to build diplomacy in international communication. Therefore, this study recommends that the government supports Indonesian students in establishing Indonesian cultural centers in various friendly countries where Indonesian students study.

This is an open-access article under the CC-BY-SA license.

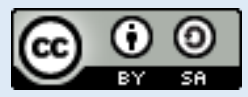

\section{Introduction}

Cultural diplomacy is a cultural exchange effort between two or more cultural groups carried out to strengthen cooperation between groups and advance national interests. Meanwhile, cultural diplomacy between nations is an effort of cultural exchange between two or more nations that is carried out to strengthen cooperation between countries and advance their respective national interests. Country [1]. Diplomacy is one of the essential instruments in implementing the interests of a nation. Diplomacy is the primary tool in achieving national interests relating to other countries or international organizations. It is through this diplomacy that a government can build an image of itself. In relations between nations, diplomacy is intensified from the earliest stage of a country establishing bilateral relations with other nations until they develop further links [2]. Cultural diplomacy is needed in promoting, campaigning, and disseminating things that many people think need to be known, especially by other nations. Cultural diplomacy can also be interpreted as diplomacy that utilizes cultural aspects to fight for national interests in the international community arena (soft diplomacy). Cultural diplomacy is also considered a tool to show the level of civilization of a nation. Another definition of cultural diplomacy is a technique of utilizing the dimensions of wealth in relations between countries. Diplomacy and communication between countries have implications for intercultural encounters, manifested as a pattern of inter-subjective and inter-manipulative relationships. Therefore, the intercultural meeting must be seen as an event that is not value-free, highly dependent on the national interests of the nations involved in diplomacy [3]. 
Diplomatic relations between Indonesia and China have officially been opened since June 9, 1950. In fact, in November 1953, the two parties signed the first trade agreement in Beijing, although the period 1967-1990 was marked by a freeze in diplomatic relations between them. It was only on February 24, 1989, when President Soeharto met the then PRC Minister of Foreign Affairs, Qian Qichen, at Emperor Hirohito's funeral ceremony in Tokyo, that the normalization of relations between the two countries was currently frozen. Finally, on July 3, 1990, the two countries signed "The Resumption of the Diplomatic Relations between the Two Countries" in Beijing. They were followed by PM Li Peng's visit to Indonesia and witnessed the signing of the Memorandum of Understanding (MoU) on the Restoration of Diplomatic Relations between the two countries on August 8. 1990. President Soeharto also paid a return visit on November 14-18, 1990, and signed the Joint Commission on Economic, Trade, and Technical Cooperation formation. The normalization of RI-PRC relations then gradually opened relations for ASEAN-PRC until finally, the PRC became a full dialogue partner of ASEAN in 1996 [4].

After the New Order, especially in Abdurrahman Wahid's government (1999-2001), China received a unique Indonesian foreign policy position, as indicated by being the first country that Abdurrahman Wahid visited after he was appointed President. President Wahid's visit on December 1-3, 1999 became a new chapter of enhancing bilateral relations between the two, which was marked by China's willingness to provide financial assistance and credit facilities, including the agreement on cooperation in finance, technology, fisheries, tourism, and countertrade in the energy sector, namely exchanging Indonesian LNG with Chinese products. In Megawati Soekarnoputri's administration, an MoU was signed to form an energy forum between the two countries, which is an umbrella for Chinese investment in Indonesia in the energy sector. Relations between RI-PRC reached their peak with the signing of the Declaration of a Strategic Partnership (Strategic Partnership) on April 25, 2005, in Jakarta. This strategic partnership includes cooperation in the fields of politics and security, economy and development, and socio-cultural and other collaboration. After the signing of this Joint Declaration, relations between the two countries developed rapidly [5]. To this day, Indonesia and China often communicate in various meetings involving the two countries; even Indonesia is one of the countries that often participate when China holds an event in its country. One of the significant events routinely held by China and always attended by participants from Indonesia is the China International Import Expo, and this can be seen in Figure 1. The exhibition was held jointly by the Ministry of Commerce of China and the Shanghai Municipal Government. Its partners include the World Trade Organization (WTO), the United Nations Conference on Trade and Development, and the United Nations Industrial Development Organization. The Chinese import fair has an obvious objective, replacing US products with products from other countries. Moreover, in the end, improve Chinese products with technology imported from other countries. They are making China the largest importing and consuming country in the world [6].

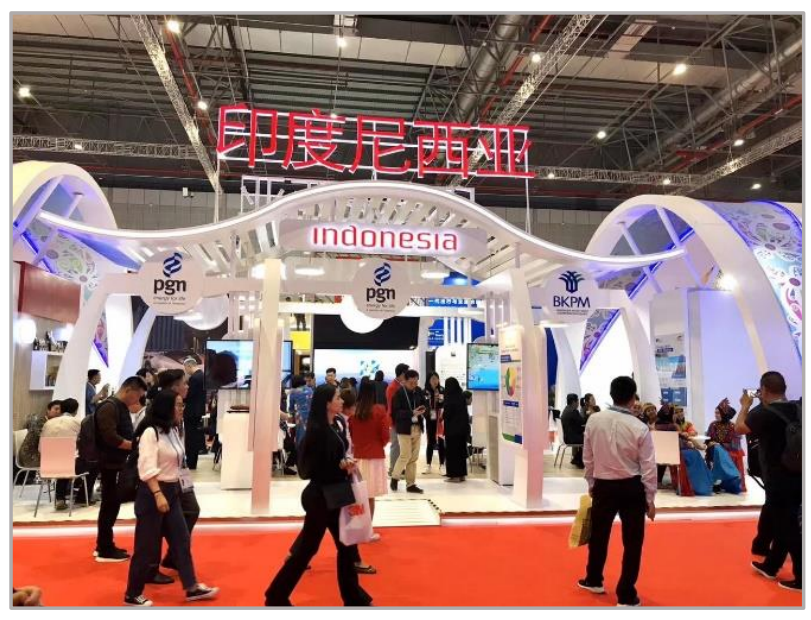

Fig. 1. Indonesia Participation in China International Import Expo

When the meeting took place, the participants displayed the products offered for international trade and showed their respective traditional uniqueness, from food, songs, dances to the traditional arts of their respective countries. The contingent from Indonesia consistently performs Indonesian dances and songs every year. However, they also showcase the diversity of Indonesian cuisine, but still, 
Indonesia's dances are the moments most awaited by the participants who enliven the event. After the last performance, Indonesia's contingent received standing applause with a typical Acehnese saman dance; this time, the Indonesian delegation also performed a typical Papuan Yospan dance. Unlike the original Yospan dance, the Indonesian contingent's dance has several movements that the dancers deliberately renew. In this paper, the author wants to describe how the typical Papuan dance performed by a contingent of Indonesian dancers at the China International Import Expo is a form of soft Indonesian diplomacy.

\section{Theoretical Framework}

\subsection{Soft Diplomacy}

Indonesia is a country that has cultural diversity, which in each region has its characteristics. Since centuries ago, Indonesian culture has been formed with a very diverse society consisting of 600 ethnic groups and having diverse cultures. Culture is an effective medium for diplomacy because it has universal elements (cultural universals), which are found in all cultures of the world's nations. In the 1990s, Indonesia began to hold cultural exhibitions in the United States. This exhibition shows the world community the various forms and innovative products of Indonesian artists. This exhibition is considered successful and has received a positive response from the US public. Indonesia. Cultural presentations at the international level are intended to introduce the cultural richness that Indonesia has. The world community highly appreciates Indonesian culture by learning Indonesian culture from songs, dances, crafts, and others. Cultural diversity is a vital force in maintaining the Indonesian nation's integrity amid the various challenges that are currently being faced. Also, Indonesia's cultural diversity is a strength for the Indonesian government in diplomacy between countries; even cultural diplomacy can bridge conflicts between nations [7]. Soft Power Diplomacy is implementing Indonesia's relations with other countries and international entities by using the ability to attract attention and cooperate, change and influence public and social opinion through various channels. Indonesia, to bridge the world differences today, will always play Soft Power Diplomacy [8]. In the opening of the 2016 Indonesia Channel show, Minister of Foreign Affairs of the Republic of Indonesia Retno L.P. Marsudi said, "With the various conflicts that occur, it certainly requires many bridges and not just one or two bridges to connect between different cultures, different religions, and other interests, and this is the part that Indonesia wants to play to build millions of bridges. So that the world can be peaceful and stable through arts and culture"[9].

Culture is a diplomatic tool for Indonesia to bridge the differences in today's world. A culture is a diplomatic tool that can unite the people of a country with the people of other countries because the culture in a nation is very much attached to all circles of society, and culture is very much attached to everyday life so that culture becomes very influential in the life of the people in the state. Cultural strength becomes an important tool that can be used to bridge the existing conflicts between one country and another [10]. For this reason, Indonesia, with its rich cultural diversity from Sabang to Merauke, uses the cultural strength of its own country to carry out Soft Power Diplomacy to bridge differences and conflicts that occur in the world today, one of which is by providing the Indonesian Arts and Culture Scholarship (BSBI) which starts from 2003. This scholarship provides opportunities for children and young people from Asian, European Pacific, and American countries to learn Indonesian culture such as playing gamelan music, dancing, making plaits, painting, making batik, etc.

\subsection{Culture and The International Communication}

International Communication is communication carried out by communicators representing a country - to convey messages related to their country's interests - to communicants who represent other countries [11]. As a study field, International Communications focuses attention on the entire process through which data and information flow through national boundaries. The subject to be studied is the current itself and the structure of the flow that is formed, the actors involved in it, the means used, the effect that is generated, and the underlying motivation. Judging by the perpetrators, international communication can be seen as divided between; (1) Official Transaction, namely communication activities run by the government; (2) Unofficial Transaction or also known as transnational interaction, namely communication activities involving non-government parties. As one of the main actors of international communication, the government takes several steps that affect the 
state's position it represents in the global political arena. The government can carry out steps that directly affect political effects, such as diplomacy and propaganda, or steps that indirectly impact, such as: promoting international education. International communication activities can take place between people to people or government to government. Markham states that the primary unit observed in international communication is the interaction between two or more countries which is Mass Mediated Communication [12]. Strictly speaking, international communication is also the study of various kinds of Mass Mediated Communication between two or more countries with different cultural backgrounds. These background differences can be differences in ideology, culture, economic development, and differences in language. Groups carry out cultural missions with the capacity as Indonesian traditional and pop artists to carry out their activities by playing musical instruments, singing, dancing, and acting about Indonesian traditional cultural arts in front of audiences with different cultures abroad [11]. Dance, literature, music, make-up, property, and costumes can show the characteristics or social identity of a particular ethnic or ethnic group in Indonesia. Internally and externally, it is not only entertaining but also displays specific cultural values. Each dance has its charm, not only the magic of the costumes but also the songs' movements and lyrics, for example, in the Saman Dance from Aceh. The dance that contains literature is one of the nation's art and culture elements that can be displayed and proud of. This is evidenced by the communication effect arising from the performances of Indonesian cultural mission groups performing overseas. They always get the highest rank and are respected in the land of people [13].

The proof is in the display of Indonesian traditional arts abroad; viewers from different cultural backgrounds can absorb the art's essence on display that can amaze and impress these foreigners. Cultural diplomacy is known as an activity to utilize culture in Indonesian foreign policy. A cultural diplomacy is a tool for exchanging ideas, information, and art among countries or communities. In cultural mission activities, a series of displays of traditional cultural arts is one of the means of intercultural communication that can positively lift negative stereotypes and prejudices inherent in the Indonesian nation [14]. This cultural strategy has helped build cultural diplomacy between the Indonesian government, and the countries visited to carry out cultural missions. The cultural mission can be seen from the involvement of a contingent of Indonesian dancers at the China International Import Expo, which can be seen in Figure 2. It is hoped that this nation's generation will be able to instill the noble roots of Indonesian art and culture to the next generation so that they become part of their soul and dignity as the Indonesian nation. This will result in not uprooting the country's cultural roots from the nation's future generations so that they do not just follow the waves that are blown away by the foreign culture [15]. Through creative steps, young people who carry out a cultural mission can strengthen their identity as civil and cultured stewards of the nation that is not uprooted from cultural roots. Because culture is the determinant of young Indonesians' identity amid globalization and all Indonesian youth must be cultural ambassadors everywhere.

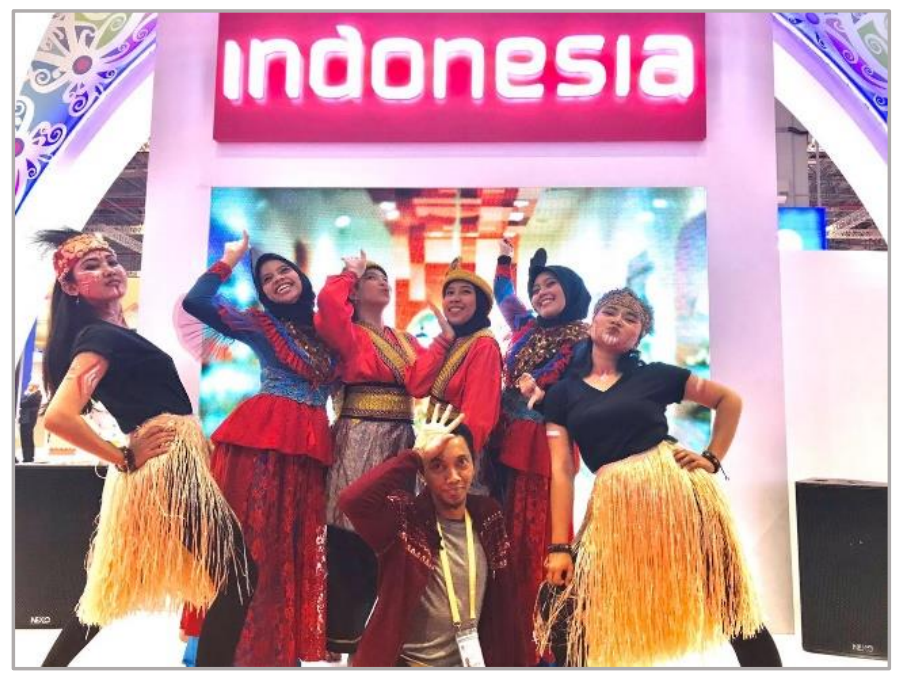

Fig. 2. The contingent of Indonesian dancers in the China International Import Expo 


\section{Method}

This research is field research. The term field study is a term that is often used in conjunction with the term ethnographic study [16]. The authors also explained that field research is also often called ethnography or participant observation research. However, according to Harrison, ethnography is only an extension of field research. Ethnography redefines how field research must be carried out. According to Roice Singleton, field research comes from two related traditions, namely anthropology and sociology, where ethnography is an anthropological study, and ethnomethodology is a study of sociology [17]. Ethnography provides answers to the question of whether the culture of an individual group, while ethnomethodology provides answers to how people understand their daily activities so they can behave in socially acceptable ways. Field research is a qualitative study in which researchers observe and participate directly in small-scale social research and observe local culture. Many students are happy with field research because they are directly involved in the association of several groups of people who have a unique attraction. There is no scary math or complicated statistics, no abstract deductive hypothesis. Conversely, there are social interactions or face-to-face with "real people" in a particular environment [18]. In fieldwork, researchers individually talk and observe directly the people being researched through interaction over several months or years of learning about their neighbors, their life history, their habits, hopes, fears, and dreams.

Researchers meet new people or communities, develop friendships, and discover new social worlds; this is often seen as fun. However, field research is also time-consuming, emotionally draining, and sometimes physically dangerous [19]. When should we use field research? Field research is conducted when research questions include learning about, understanding, or describing the interactions of a group of people. This is usually done if the question is: What about people in the social world? Or What is the social world of X? This can be used when other methods (for example, surveys, experiments) are considered impractical. Douglas stated that some of what social researchers really want to learn could be learned only through the direct involvement of a researcher in the field. A simple method of field research observations (Field Research) can be defined that is directly conducting observations to obtain the information needed in the preparation of this final project report. For example, when researchers want to examine how the role of opinion leaders in the Kajang tribe, it uses the field research method to obtain accurate and precise results, where researchers come to live, socialize and carry out other social activities in order to get conclusions that are appropriate from what is in the field. Therefore, this research was conducted by the author following the routines of Indonesian students who are actively becoming ambassadors of Indonesian culture at every opportunity, especially when they will carry out Yospan dance performances. There the author collects various information needed to write this research report.

\section{Results and Discussion}

Indonesia consists of various distinctive cultures that portray Indonesia's identity as a large nation as an archipelagic country. Ethnic and ethnic diversity is the source of how culture is produced. For example, different kinds of traditional dances contain oral literature in them, namely poetry or rhymes that reflect Indonesian society's social aspects. Indonesian traditional dances and music have become an identity for introducing Indonesia to the international arena as a national cultural heritage. On several occasions, the young generation who represents Indonesia in the international arena has always attracted the global public's attention through traditional dance and music performances. This is done by following or holding a cultural mission program to promote national interests and expand dialogue with relations abroad. The artistic mission program plays an increasingly vital role in carrying out a country's mission, especially in a situation that is increasingly integrated with its very varied fields. The advantages that literature gets from the cultural mission program are: As a form of culture, Indonesian traditional dance will be known in other countries. Strengthen relations between people and other countries as a bridge for government relations, As a form of recognition that Indonesia is a country that has high arts and culture, especially traditional dances. Yospan dance is a type of social association dance in Papua. Where young people often play it as a form of friendship. Yospan stands for Yosim, and Pancar is a traditional dance originating from two regions in Papua, namely Biak and Yapen-Waropen.

Initially, Yospen consisted of the social dance of Yosim and Pancar. The two dances are different but eventually combined into one. In Yosim's performance, which came from Yapen-Waropen, the 
dancers invited other residents to be immersed in the songs sung by a group of singers and music instrument holders. Also read: Salai Jin Dance, North Maluku Traditional Dance The musical instrument used is simple, which consists of catfish and guitar, which are musical instruments from outside Papua. There is also a tool that functions as a bass with three ropes. The rope is usually made from rolled fibers, a type of pandanus leaf, which can be found in the forests of Papua's coastal areas. Then there is the Kalabasa musical instrument. The tool is made of dried pumpkin, then filled with beads or small stones that are played by simply shaking it. Quoted from the Irian Jaya Regional Monograph book (1980), the Yosim dance movement is effortless. The women wear woven sarongs to cover their chests, decorative heads with flowers, and bird feathers. For male dancers wearing shorts, open trunks, the director also decorated with bird feathers.

Meanwhile, the Pancar dance originating from Biak is only accompanied by Tifa. Tifa is the traditional musical instrument of all coastal tribes in Papua. Also, read Gong Dance, Typical Traditional Dance of East Kalimantan. For the movements, it is not agile and has many styles as in Yospan. The transmitting dancer's movement is relatively stiffer because it follows the beat of the musician's hand blows on the Tifa skin, which is usually made of soa-soa (lizard) skin. Then the two dances were combined into one with the name Yospan dance (Yosim-Pancar). The Indonesian contingent chose this dance because, in addition to being unique, it also has a value of friendship in its movement. The Yospan dance types have five motion modes, with the Yosim motion as an intermediate or joint motion from one motion mode to the next. Five types of Yospan dance movements, among others;

- Motion Wipe; a variety of motion in which the dancer walks forward with a count of each footstep stomped on the ground (stage/stage) twice. The range of motion has variations, namely regular wipe and five rotating positions in place. The Seka movement originates from the social dance of the ethnic groups who inhabit the southern part of Papua's island, to be precise, Timika, Kaimana, to Fak Fak.

- Gerak Pacul Tiga; This motion is called the Maneru Pancar (name of a place in the interior of the island of Biak). In this motion, the dancer strolls forward three steps in the third step, stops, and throws his right/left leg forward, to the left and right side facing forward while bending/bending and back upright. This movement is often carried out at people's parties.

- Gale-Gale motion; a motion in which the dancer walks forward with a count of 4 steps ahead on a count of four feet dragged on the ground. There are two variations of the gale-gale motion: the regular gale-gale and the back and forth gale-gale. This movement is influenced by the social dance of Wondama Bay and the Mor-Mambor islands, known as the Balangan dance.

- Gerak Jef, the jef movement in the Yospan dance, is a movement that is influenced by rock and roll dance. This movement emerged around 1969-1971. The jef movement is a movement that is carried out in the first count of stomping the right foot twice while in front, and the body is slightly oblique, then jumping up and down, throwing the left and right legs with a count of four steps and returning to the first movement. There are four variations of the jef, namely, regular jef, snake jef/ zig zag, robot/step jef, and jef sengsor. These movements are inspired by outside Papua.

Motion Transition; a transmission motion in which the dancer strolls forward three steps. The third step count is done by jumping ahead by landing two feet (left and right foot) on the ground (stage). The transmit motion has four variations of action, namely, regular transmitting (one time transmitting), Suntung transmitting (two times transmitting), Transmitting arrogant (three times), and Transmitting skipjack. This motion is inspired by animals and environmental, behavioral conditions around it. Of the five basic movements in the Yosim Pancar (yospan) dance above, there is one more movement: the Yosim motion. The Yosim sign is an erratic movement when dancing from one activity to the next, always followed by a yosim motion. The Yosim Pancar (yospan) dance is danced by men and women together in pairs with various patterns developed and accompanied by accompanying music. In its development, the Yospan dance is currently undergoing changes, especially seen in the addition of variations in motion that are no longer by the movements that have been standardized by the Papuan Land Arts Council. Then the formation of patterns and costumes is increasingly varied. The involvement of cultural issues in international relations is often remembered as limited to the arts' performance, such as art trips or art fairs to foreign countries. Globalization's effect on cultural identity 
prioritizes economic and political approaches, which are believed to invite controversy and even reduce the quality of interaction intensity. Performing, arts, dance, music, and theater, can show a particular ethnic or ethnic group's social characteristics or identity. Internally and externally, it contains entertainment and can also tell stories, educate, and even teach specific cultural values. The series of displays of Indonesian traditional cultural arts carried out abroad (cultural missions) can take turns and stir up the audience's emotions. This is a superstructure means in the form of an exhibition with recognition (recognition).

Immediately it also uproots the stereotypes and prejudices that have been inherent in the Indonesian nation. This intercultural communication strategy has proven capable of building cultural diplomacy and changing the world community's skewed view about Indonesia's weaknesses. Practically, traditional dances and literature on cultural missions will serve to disseminate investment in cultural diplomacy and assist the government in drafting regulations and provisions covering people's lives from cultural diversity. Also, the artistic mission can build and maintain the spirit of freedom of imagination, expression, and opportunity for all elements of society in the variety of cultural arts as the nation's greatest asset. On the other hand, a cultural mission can change people's awareness and behavior regarding intellectual property and cultural heritage protection. If we look further, we will find that cultural relations in international relations can be more than that. It can be said that the problem of international relations is mainly cultural. Just as we interact with fellow humans, to interact with other countries, we need an understanding of a culture so that the process of friendship or cooperation can take place smoothly. Thus, understanding, knowing the habits, customs, taboos, preferences, and procedures of a country's inhabitants is expected to minimize offense that may arise in communicating. So, understanding culture is critical in international relations. This cultural understanding itself can be seen in the protocol habits or procedures arranged in meetings, for example, negotiation protocol languages, where the guidelines for respecting, greeting, expressing opinions, asking questions, proposing are organized and guided in such a way. Cultural understanding is, of course, necessary for the success of negotiations or collaborations.

Cultural relations and other international relations can be expressed in the framework of Cultural Diplomacy. In this case, diplomacy as one of the studies of international relations is defined as negotiation and how to manage relations between nations both in a peaceful state and (especially) in a situation of war. Therefore, cultural diplomacy can be stretched from micro where culture can be considered artistic things and studies that are macro who believes that the management of relations between nations certainly involves aspects of culture in a broad sense. Furthermore, cultural and international relations can also be understood through the concept of Soft Power by Joseph Nye. "Soft power is the ability to get what you want through attraction rather than coercion or payments. It arises from the attractiveness of a country's culture, political ideals, and policies. When our policies are seen as legitimate in the eyes of others, our soft power is enhanced. "Thus, cultural elements belonging to a country which are packaged in such a way, are exploited, then can be used as a means to attract the attention of other countries, thereby inviting cooperation and ultimately carrying out the interests of the respective countries concerned. In the end, several things can be noted that the actual application of cultural diplomacy can be made by anyone (for Indonesia, this is made possible by what is known as multitrack diplomacy); it must be integral and synergize with foreign policy and other programs coordinated by the Ministry of Foreign Affairs. The success of cultural diplomacy is also determined by the factors of economic strength, political authority, military strength, and the consistency of its implementation because the fundamental goal of cultural diplomacy is opinion formation. So cultural diplomacy will often be very effective and relevant to be carried out by developed countries that have the power to support their diplomacy.

\section{Conclusion}

The cultural mission is an art and cultural group that performs Indonesian traditional arts abroad. The artistic mission is a concrete manifestation of how they, as part of the nation's children, "talk" to the world about Indonesian cultural civilization. They will convey what they understand about the nation's cultural wealth. Indonesian people live in several places and areas, such as mountains, coasts, or even cities. These places and regions generate the potential for rich cultural wealth and beauty. The artistic results are diverse, such as buildings, traditional weapons, clothing, food, arts, including literature and dance. A dance that contains literature in it is not a mere performance but a form of 
cultural communication to understand culture itself. Also, traditional Indonesian dances and the lyrics in them, in this case, is literature, are one way to understand Indonesia's diversity. The Indonesian cultural mission team introduced to dance and literature as cultural products that contained Indonesian values reflected in movement and lyrics: music, make-up, props, and traditional Indonesian costumes to the international scene. Traditional dances and literature in the mission of culture are one of the tools of cultural diplomacy. It is the mission to change the stereotypes and prejudices of foreigners about Indonesia. Also, the artistic mission is a place to express skills and works of art to the international community. It can increase the awareness of the younger generation towards the nation's arts. Thus, the existence of a cultural mission program is urgently needed by Indonesian representatives in countries that have diplomatic relations with Indonesia to open global skills and cultural networks, an exchange of artistic creativity. Between the world, and provide a good perspective on Indonesia through dance, literature, and music. This cultural mission is increasingly central when other economic, social, and political factors can no longer be used as tools for diplomacy.

\section{References}

[1] D. Clarke, "Cultural Diplomacy," in Oxford Research Encyclopedia of International Studies, 2020. doi: 10.1093/acrefore/9780190846626.013.543

[2] D. Fadillah, Z. Nuryana, M. Sahuddin, and D. Hao, "International-Cultural Communication of the Saman Dance Performance by Indonesian Students in Nanjing," Int. J. Vis. Perform. Arts, vol. 1, no. 2, pp. 98 105, Dec. 2019, doi: 10.31763/viperarts.v1i2.70.

[3] J. M. McCormick, "Diplomatic History," in Routledge Handbook of American Foreign Policy, 2015. Available at: Google Book.

[4] D. Fadillah, "Belt Road Initiative in the Simulacra Analysis (Indonesia - China Relationship in the Perspective of Indonesian Students in Nanjing City)," ASPIKOM, vol. 5, no. 1, pp. 63-71, 2020. doi: 10.24329/aspikom.v5i1.493

[5] L. C. Sinaga, "The Dynamics of Indonesia-China Relations in Politics, Defense-Security, and Economy in Southeast Asia: An Indonesian Perspective," in Six Decades of Indonesia-China Relations, Springer, 2018, pp. 1-15. doi: 10.1007/978-981-10-8084-5_1

[6] L. Zou, China International Import Expo: Shared Future in a New Era. World Scientific, 2020. doi: $10.1142 / 11925$

[7] C. S. Dewi, "Cultural policy and the rise of multiculturalism study of fine arts exhibition in the 2000s, the national gallery of Indonesia," Int. Rev. Humanit. Stud., vol. 5, no. 1, pp. 320-332, 2020, doi: 10.7454/irhs.v5i1.240.

[8] F. D. Putra and S. Smolek, "Peace language and conflict resolution in harmony communication," Int. J. Commun. Soc., vol. 2, no. 2, pp. 86-93, Aug. 2020, doi: 10.31763/ijcs.v2i2.134.

[9] Ministry of foreign affairs of the Republic of Indonesia, "Ministry of foreign affairs of the republic of Indonesia," Ministry of foreign affairs of the Republic of Indonesia, 2016.

[10] U. Jandevi and M. Zareen, "Cross-cultural communication of the Indonesian students in China," Int. J. Commun. Soc., vol. 2, no. 2, pp. 79-85, Aug. 2020, doi: 10.31763/ijcs.v2i2.96.

[11] F. Nurislamia and E. S. Asriya, "International communication dynamics of American intervention efforts to democratize in the arab spring through forward strategy for freedom in the middle east," Int. $J$. Commun. Soc., vol. 1, no. 2, pp. 82-88, Sep. 2019, doi: 10.31763/ijcs.v1i2.37.

[12] K. Jaya, "Venezuela's communication dynamics in rejection of humanitarian assistance from United States of America," Int. J. Commun. Soc., vol. 1, no. 1, pp. 26-33, 2019, doi: 10.31763/ijcs.v1i1.5.

[13] M. I. Cohen, "Three Eras of Indonesian Arts Diplomacy," Bijdr. tot Taal-, Land- en Volkenkd., 2019, doi: $10.1163 / 22134379-17502022$.

[14] Y. A. Ulyana and M. A. Salleh, "The Role of Cultural Diplomacy: Indonesia-Malaysia Relations," Asian People J., 2018. Available at: Google Scholar.

[15] N. Viartasiwi, A. Trihartono, and A. . Hara, "Unpacking Indonesia's Cultural Diplomacy: Potentials and Challenges,” Int. J. Sustain. Futur. Hum. Secur., 2021, doi: 10.24910/jsustain/7.2/2331. 
[16] D. Collector and F. G. Module, "Qualitative Research Methods Overview," Qual. Res. Methods A Data Collect. F. Guid., 2011, doi: 10.2307/3172595.

[17] A. K. Harrison, Ethnography. 2018. doi: 10.1093/oso/9780199371785.001.0001

[18] J. A. Maxwell and L. E. Reybold, "Qualitative Research," in International Encyclopedia of the Social \& Behavioral Sciences: Second Edition, 2015. doi: 10.1016/B978-0-08-097086-8.10558-6

[19] S. J. Tracy, "Qualitative quality: Eight a"big-tent" criteria for excellent qualitative research," Qual. Inq., 2010, doi: 10.1177/1077800410383121. 